\title{
Associate of Engineering
}

National Cancer Institute

\section{Source}

National Cancer Institute. Associate of Engineering. NCI Thesaurus. Code C71343.

An associate's degree awarded upon completion of a course of study, usually lasting two years, with a focus on eng ineering. 